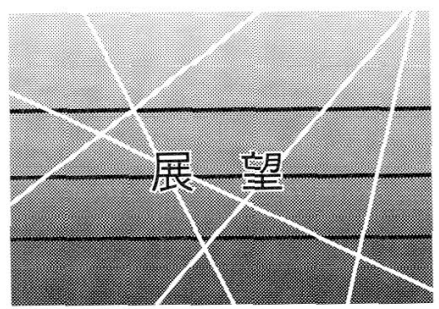

\title{
21世紀に向けた発電プラント用材料
}

\author{
新田明 人*
}

1. は じめに

最近, 気候温暖化, 酸性雨等の地球規模の環境問題が国際 的に大きな関心を集めている. このうち温暖化の元凶となっ ている二酸化炭素 $\left(\mathrm{CO}_{2}\right)$ 亿注目すると, 我が国では, 電力分 野が $\mathrm{CO}_{2}$ 排出量の約 3 割を占めており, その削減対策が緊 急の課題となっている、とりわ壮, 化石然料を用いる火力発 電には燃料消費量の抑制をはかる高效率化が不可久となって いる. そのため, 現在蒸気条件の一層の高温・高圧化を進め た超々臨界圧汽力プラント, 超高温ガスタービンと蒸気ター ビンを組み合わせを複合発電プラントなどの開発・実用化が 進めら机て㧍り, 将来的には複合発電が基本となるものと考 えられる。これらは，いずれも高温化によって高效率化を実 現しょらとするものであり，その使用環境はますます過酷な ものとなっている。したがって, これらの発電用高温機器に 使用される材料火は優れた高温強度等が要求されることとな り, 新しい材料への期待も大きい.

そこで，ここでは，21世紀中葉采での超長期仍ぶ火力 発電プラント技術の見通しに立ち，兑北を支党る材料技術に ついて展望する。

\section{21 世紀に求められる火力発電の姿}

上述した地球規模の環境問題への対応の一環として, 気候 温暖化の原因之なる $\mathrm{CO}_{2}$ の排出を抑制する国際的な動きが 高亲りつつある. 我が国では, 地球温暖化防止行動計画が 1990年10月に策定されたが，これ尤ると，2000年以降の 国民 1 人当たりの $\mathrm{CO}_{2}$ 排出量を拈拈む称1990年レベルで安 定化することを目標としている。我が国の1990年現在の $\mathrm{CO}_{2}$ 排出量は約 3.2 億トンであり，上述したように，そのう
ちの約 3 割を占める電力分野に拈いては，化石燃料を使用 する火力発電の高効率化が不可欠となっている.

電力中央研究所 ${ }^{(1)} 2010$ 年には1988年の約1.6倍, 2050 年 には約 2.5 倍になるものと想定して火力発電に上る $\mathrm{CO}_{2}$ 排出 量の推移を予測している，午の結果を図 $1^{(1)}$ に示すが，同図 には発電効率が向上する場合と向上しない場合の 2 ケース を併示している。これを見ると，発電効率を垷状維持とする 場合の $\mathrm{CO}_{2}$ 発生量は2000年にピークを示した後，2010年ま で減少している。これは，当初原子力等の非化石ェネルギー の電源設備が電力需要に追いらが゙，火力発電の増大により $\mathrm{CO}_{2}$ 発生量も增加するものの, その後電力需要の伸びの鈍 化之非化石エネルギーに上る供給力の強化に上り一時的に低 下寸ることを示唆している。しかし，その後は，非化石ェネ ルギーの開発を最大限期待しても, 徐々に $\mathrm{CO}_{2}$ 発生量は増 大していき，2050年まで1990年のレベルを上廻ることとな る。一方, 発電効率が向上する場合は, 高効率新型火力発電 を最大限導入するものであり，初期の抑制効果は小さいも

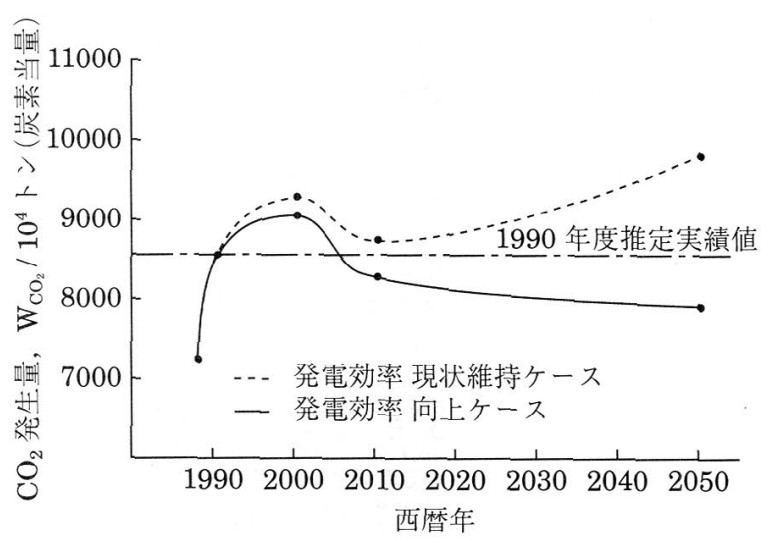

図 1 火力発電の高効率化に上る $\mathrm{CO}_{2}$ 発生量の予測(1).

* (財)電力中央研究所狛江研究所 金属材料部次長 (广201 狛江市岩戸北2-11-1)

Advanced Materials for Power Plants Toward the Twenty-First Century; Akito Nitta (Komae Research Laboratory, Central Research Institute of Electric Power Industry (CRIEPI), Komae)

Keywords: power plants, high temperatures, structural material, material development, advanced alloy, intermetallic compound, ceramic, composite

1994年 6 月 21 日受理 
のの, 2005年以降は1990年のレベル以下になっている. し たがって, 火力発電の高効率化が長期的に $\mathrm{CO}_{2}$ 発生を抑制 し行動計画の目標達成に大きく貢献することになる.

図 2(1) は，発電効率向上ケースの基本となる高効率新型火 力発電技術の実用化時期とその達成可能な効率をまとめたも のである.

我が国では，1967年に蒸気圧力 $24.2 \mathrm{MPa}$ 超臨界圧プラ ントが初めて運開して以来, 超臨界圧プラントの導入が進み, 40\%の最高効率を達成するに至った. その後, 1980年代ま で蒸気条件の大きな改善は見られなかったが，1980年代に 入ると, 上述した地球規模の環境問題への対処のため, 再び 高効率化が進められることとなり, 蒸気条件の超々臨界圧 (USC) 化やガスタービン (GT) と蒸気タービンとの複合発電 化が注目されるよらになった。

USC プラントの技術開発は，1979年頃から開始され，そ の開発目標として，ステップ I では圧力 $31.0 \mathrm{MPa} \cdot$ 温度 $866 \mathrm{~K}$, ステップ II では圧力 $34.5 \mathrm{MPa} \cdot$ 温度 $922 \mathrm{~K}$ が設定 され, 従来の超臨界圧プラントの熱効率に比べ, 相対值でそ れぞれ $6 \%$ 执よび $8 \%$ の向上が見达まれることとなった ${ }^{(2)}$.

一方, ガス・蒸気複合発電プラントでは, 1984年以降運 開された東北電力(侏東新潟 3 号系列が液化天然ガス (LNG) を燃料とした $1370 \mathrm{~K}$ 級 GT を採用し, 約 $44 \%$ の高効率を達 成した ${ }^{(3)}$. 現在, LNG 焚 GT は $1670 \mathrm{~K}$ 級が実用化段階に あるが，2000年運開予定の東新潟 4 号系列では $1720 \mathrm{~K}$ 級 GTを採用することにより $50 \%$ の高効率化が見达まれてお り, 今後は一層の高効率化を目指した $1770 \mathrm{~K}$ 級の開発が進 められよらとしている. また, 石油や天然ガスに比し埋蔵量 が数倍も豊富で, 経済性にも優れ, かつ安定供給が期待され る石炭は21世紀の我が国に打ける主要なエネルギー源と考

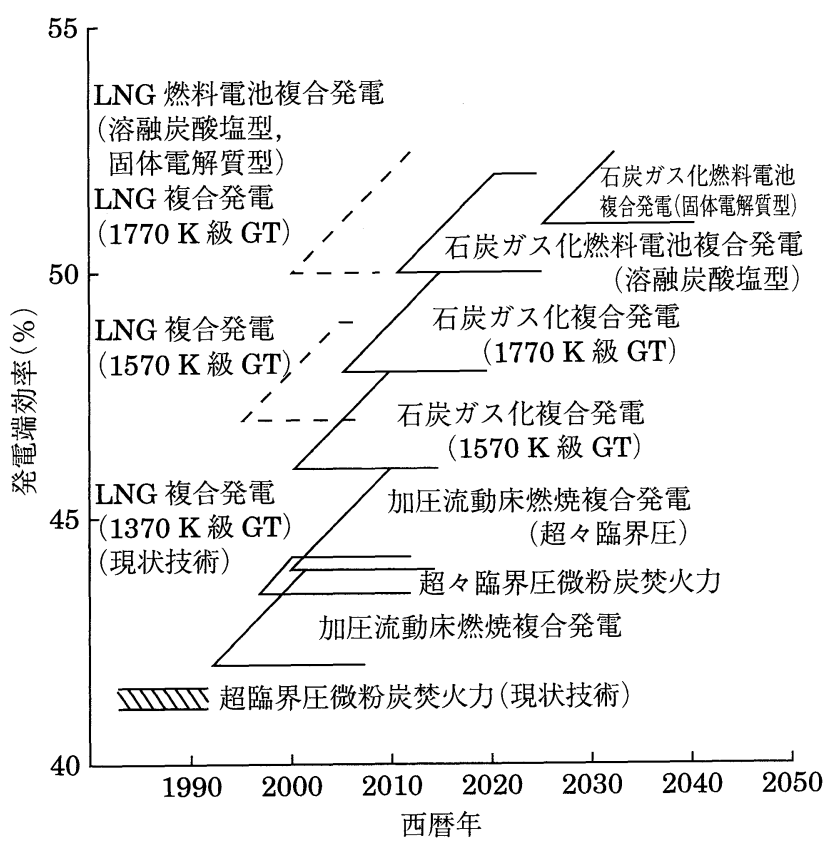

図 2 高効率新型火力発電技術の実用化の展望 ${ }^{(1)}$.
えられている.そのため, このような優れた利点をもつ石炭 の有効利用をはかる石炭ガス化複合発電が将来の火力発電の 主力と目されて扣り，国のプロジェクトとして1983年以降 開発が進められている(4).さらに，環境保全性と高効率化を 飛躍的に向上させる水素燃焼タービンを2030年に実用化さ せるため，まず要素技術の確立を図る国のプロジェクトが 1994年より開始された.

\section{3. 火力発電の高効率化を支える材料技術}

発電プラントの高性能化は, 他の機械・設備と同様, 材料 技術の進歩によるところが大きい。たとえば，ガスタービン は18世紀にアイデアの提案があったものの, 適用可能な耐 熱材料がなかったため，その実用化は1938年まで待たざる を得なかった。 また，その後のガスタービンの高性能化はガ スタービン入口温度の高温化により進められてきたが，それ は，図 $3^{(5)}$ に示すように，ガスタービン翼の冷却技術ととも に, 高温に耐えらる材料開発が大きな役割を果たしてきた. このような耐熱材料のこれまでの進歩と今後の展望について まとめると，図4 ${ }^{(6)}$ のよらになる。

以下では, 最近の材料開発の動向を踏まえ, 将来の火力発 電の高効率化のための材料技術について展望する.

\section{（1）最近の材料開発における特徵}

\section{（i）材料間の重要度の変化}

図 $\mathbf{5}^{(7)}$ は, 金属, 高分子材料, 複合材料执よびセラミック スの 4 分野に打ける相対的重要度の変遷として, 過去から 未来に至る材料の進歩を示したものである。

これを見ると, 今世紀中葉まで金属材料の重要度が増大し 続けてきたものが，それ以降次第に他の材料に取って代わら れる傾向が認められる.すなわら, 金属材料からセラミック やプラスチックといった無機・有機系材料へと重要度が移行 し, 材料の多種·多様化が進んでいる. その一例として, 図 4 に示したガスタービン等の耐熱材料においても，ガス温度 の超高温化とともに, 金属系材料からセラミック系材料へ発 展していく傾向がうかがわれる.

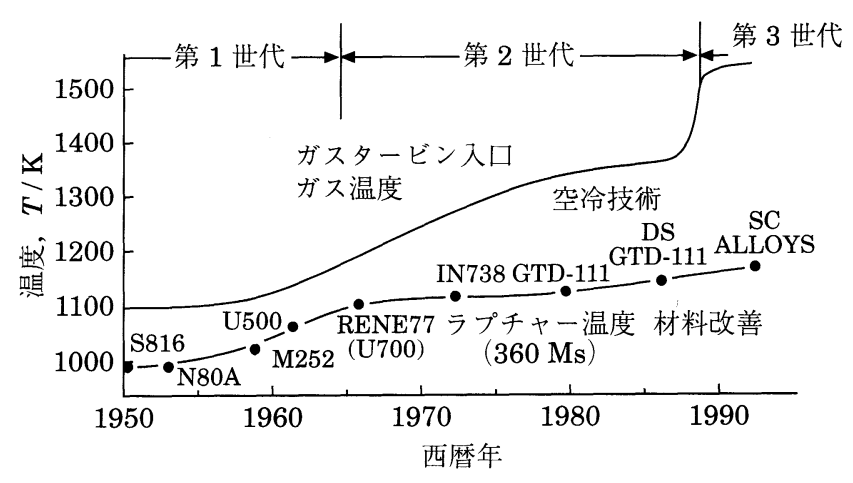

図 3 ガスタービン入ロガス温度の推移 ${ }^{(5)}$. 


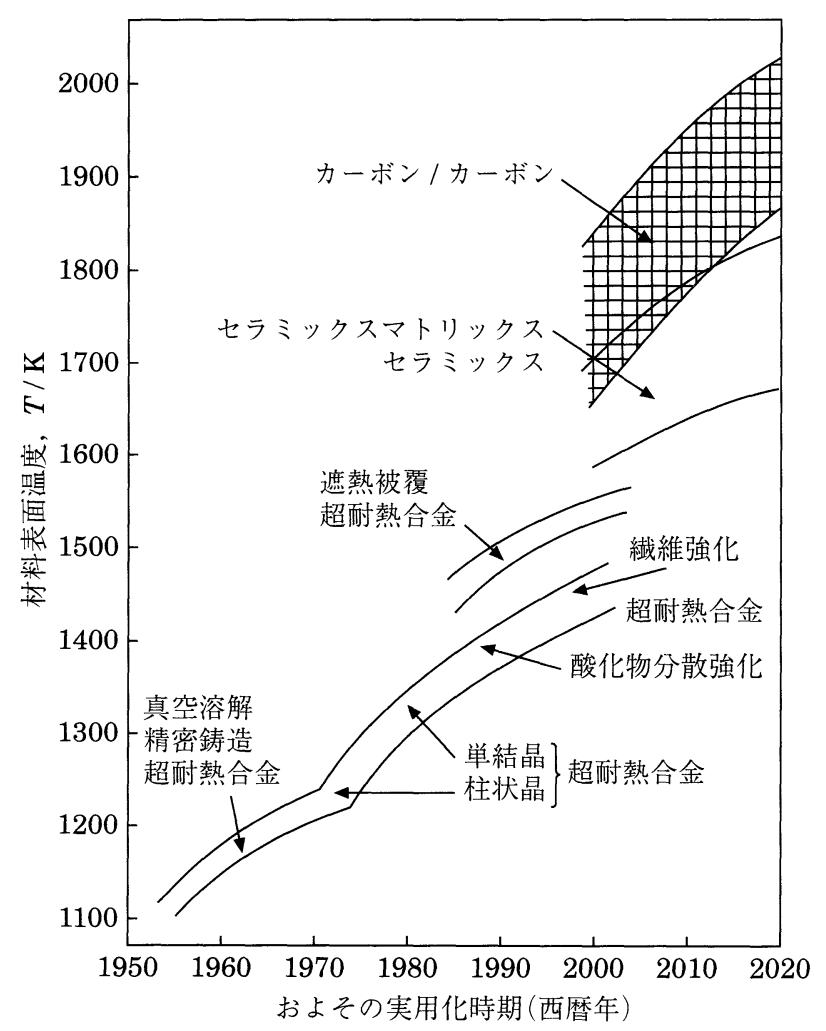

図 4 耐熱材料の開発動向 ${ }^{(6)}$.

\section{(ii) 複素・複合化の進展}

各種材料間の相対的重要度を示した図 5 から, 今後複合 材料の重要度が増大していく傾向が認められる. その具体例 として, 図 4 に示した耐熱材料の発展を見ると, 将来の超 高温耐熱材料にはセラミック系や炭素系の複合材料が有望視 されていることがわかる.このように，優れた機能・性質を もった特定の材料を単一利用してきた，これまでの段階か ら, 複数 ·多種の材料の個々の優れた機能 - 性質を活かし合
い，より一層の高性能化を目指す複素・複合化が今後主流と なるであろら。たとえば，1985年に我が国で最初にアイデ アが提案された傾斜機能材料は, 金属材料とセラミックの複 合化により，大きな熱応力低減効果等を付与しらる新材料の ひとつであり, 将来の高性能タービン翼等への適用が期待さ れる。

また，現時点では発電プラントへの適用性については未知 であるが，このよらな複素・複合化による高性能化を目指す 新概念のひとつとして, 自己診断性 (予知・予告性)や自己修 復性をもたせる材料のインテリジェント化が挙げられる.

さらに，従来それぞれ独自に進展してきた材料開発と構造 設計を融和させることにより，一層の高性能化を図る融合材 料といら新概念も提案されており, 今後の発展が期待されて いる。

\section{(iii) プロセス技術の革新}

既存材料の改良をはじめ新しい材料の創製による高性能化 は，その製造工程に持けるプロセス技術の革新に負らところ が大である.図 4 に見られる耐熱超合金の進歩においても， プロセス技術の果たしてきた役割は大きいと言える。非常に 硬く高強度の超合金によるガスタービン翼の製造には，通 常, 精密鋳造が用いられる. 従来の普通鋳造法では, 多結晶 状態となり, 高温破壊の起点となる結晶粒界が多数存在する こととなる. これに対し，高性能結晶制御を可能とする一方 向凝固鋳造法や単結晶鋳造法の開発により，数個あるいは 1 個の結晶から成るガスタービン翼が実用化され，高温強度 の一層の改善が図られた.これらの製造法は，いずれも米国 に颃いて，それぞれ1965年特よび1967年に開発されている. その後, 我が国や欧米を中心として単結晶超合金の開発研究

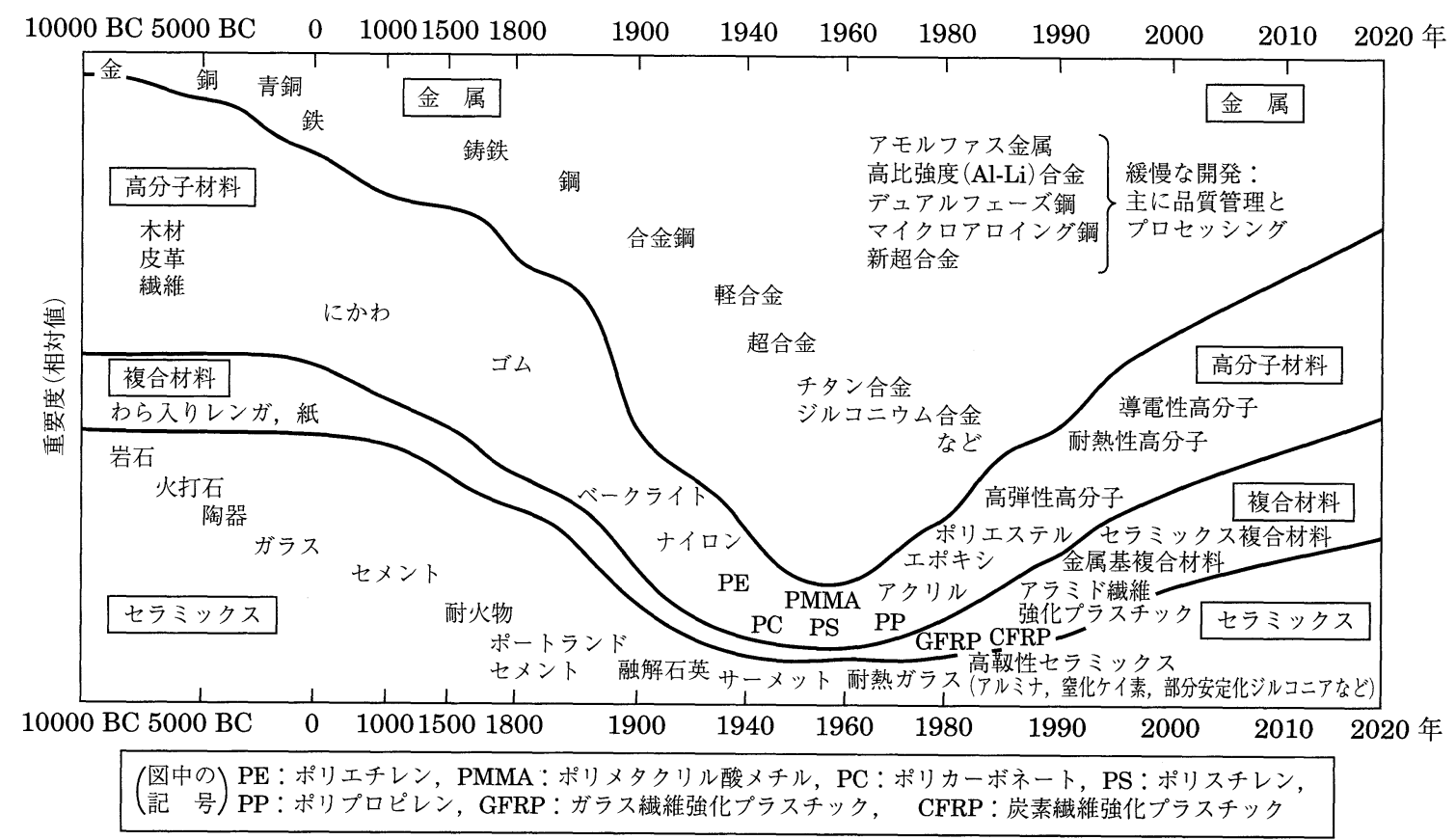

図 5 工業材料の発展 ${ }^{(7)}$. 
が進み，多くの合金が開発されている.

この他にも, 酸化物微粒子を均一に分散させ高強度化を図 る機械的合金化(メカニカル・アロイング)法に上る酸化物分 散強化型合金の開発, 金属粉末とセラミック瀻維を混合・成 形する粉末治金法による金属基複合材料の開発，原料粉末の 熱間等方加圧 (HIP) 法によるセラミック材料の成形, 急速焼 入れ法によるアモルファス合金の開発，高純度化による鋼の 強勒化, レーザービーム等による表面改質法の開発, 等が挙 げられ，プロセス技術は日進月歩の状況にある。

\section{(2) 材料技術の将来予測}

表 $1^{(8)}$ は，経済企画庁経済審議会が1992年 7 月にとりまと めた「2010年の技術的予測」のなかで分析した，我が国の 将来の産業経済に与学るインパクトが大きい新素材をはじめ とする未来技術の実用化時期を一覧したものである.このう ち, 新素材について見ると, 今世紀末まで高性能炭素緘維 強化プラスチック等の実用化を挙げて拉り，2010年までに は, 水素吸蔵合金, アモルファス合金, 高性能 $\mathrm{C} / \mathrm{C}$ コンポ ジット等の実現を予測し，それ以降21世紀中葉までに超電 導材料, 高性能七ラミック系複合材料, 高性能金属系複合材 料等について見通している.いずれにしても，今後の材料開 発研究に沶いては, 高品質・高性能・高(新)機能・高付加価 值がより一層指向されていくものと考えられる.

\section{（3） 発電効率向上のための材料技術}

USC プラントは, 従来の超臨界圧プラントの設計概念に 基づき, 高温・高圧化には使用材料の高強度化で対処しょう とするものである。したがって，その成否はまさに材料技術 の改良・開発にかかっていると言える．ステップI の USC 蒸気タービンでは, 主要部品はすべてフェライト系材料で構 成でき, 高温ローターには改良 $12 \mathrm{Cr}$ 鋼が採用されている。 これらは, 現用の $\mathrm{Cr}-\mathrm{Mo}-\mathrm{V}$ 鋼および $12 \mathrm{Cr}$ 鋼ではステップ I の温度条件に対し $360 \mathrm{Ms}\left(10^{5} \mathrm{~h}\right)$ クリープ破断強度の確保 が困難であったことから，現用 $12 \mathrm{Cr}$ 鋼の組成改善によって
高強度化したものである(2)。 また，ステップIIの高温ロータ には，さらに高温強度の高いオーステナイト系合金の採用が 不可欠であり，大形鍛造が可能な改良 A286 合金が開発され ている(9).

一方，図 3 に示したように，ガス・蒸気複合発電の高効 率化はガスタービンの高効率化，すなわち入口ガス温度の高 温化に大きく依存する．現在，ガスタービン部品には金属系 耐熱材料が用いられて拈り，特に高温部には，鉄基・コバル 卜基やニッケル基の超合金が採用されている。最近では，上 述したように, 結晶制御技術をはじめ, 粉末治金や機械的合 金化等の加工技術に代表されるプロセス技術が進歩し，さら 飞高性能の合金が開発されている(10)。な抏，このよらなが スタービン材料には, 過去の発電用ガスタービンの損傷原因 が腐食・浸食 $(47 \%)$, 疲労 $(29 \%)$, クリープ $(9 \%)$ と報告さ れている(11) ことからも, 高温強度と耐食性の両面でバラン スのとれたものでなければならないと言える。

さらに高効率化を目指した超高温ガスタービンには，セラ ミック，金属間化合物，炭素/炭素複合材料等の先進材料が 期待されている(10)。このうちセラミックは炭化けい素や窒 化けい素を中心に, 燃焼器や静翼への適用が進められてい る。セラミック静翼の一例を図 $6^{(12)}$ に示す。をた，動翼へ のセラミックの適用研究も進められている(13)が, 現在のと ころ, 遮熱効果を高めたセラミック被覆は実用化の見通しが 得られているものの, セラミック動翼の開発には未だ多くの 時間を要寸るものと思われる.ささらに傾斜機能材の発展も今 後期待される，一方， $\mathrm{Ni}_{3} \mathrm{Al}, \mathrm{TiAl}$ 等の金属間化合物は脆さ と耐酸化性の克服が不可欠であり, また，炭素・炭素複合材 料は炭素繊維の耐熱性の向上や耐酸化性被覆技術の開発が課 題とされて括り, 今後の研究開発の一層の進展が必要であ る. 特に, 水素燃焼タービンでは $2273 \mathrm{~K}$ までを想定した超 高温材料の開発が不可欠とされて拉り，高性能耐熱合金，金 属間化合物の他，セラミック系や炭素系複合材料等が注目さ れている。

表 1 わが国に拈ける未来技術の実用化時期(8)。

\begin{tabular}{|c|c|c|c|c|c|c|}
\hline \multirow{2}{*}{ 分 野 } & \multicolumn{2}{|l|}{ 1990 2000年 } & \multicolumn{2}{|l|}{ 2001 2010年 } & \multicolumn{2}{|l|}{ 2011年以降 } \\
\hline & 実用化技術 & 時期 & 実 用 化 技 術 & 時期 & 実用 化 技 術 & 時期 \\
\hline 新 素 材 & $\begin{array}{l}\text { 高性能 CFRP } \\
\text { セラミックスガスタービン }\end{array}$ & $\begin{array}{l}2000 \\
2000\end{array}$ & $\begin{array}{l}\text { 磁性材料 } \\
\text { 水素吸蔵合金 } \\
\text { 光 IC } \\
\text { 半導体超格子素子 } \\
\text { ニューガラス } \\
\text { アモルファス合金 } \\
\text { 高性能 C/Cュンポジット }\end{array}$ & $\begin{array}{l}2010 \\
2010 \\
2010 \\
2010 \\
2010 \\
2010 \\
2010\end{array}$ & $\begin{array}{l}\text { 非線形光電子材料 } \\
\text { 光化学ホールバーニングメモリ } \\
\text { 超電導材料 } \\
\text { 熱可塑性分子複合体 } \\
\text { 分子デバイス } \\
\text { 高性能 CMC } \\
\text { 高性能 MMC }\end{array}$ & $\begin{array}{l}2020 \\
2020 \\
2030 \\
2040 \\
2040 \\
2050 \\
2050\end{array}$ \\
\hline エネルギー & 高効率ヒートポンプ & 1995 & $\begin{array}{l}\text { 太陽光発電 } \\
\text { モジュール型軽水炉 }\end{array}$ & $\begin{array}{l}2010 \\
2010\end{array}$ & $\begin{array}{l}\text { 燃料電池 } \\
\text { 超電導電力貯蔵施設 } \\
\text { 高速増殖炉 } \\
\text { 核融合炉 }\end{array}$ & $\begin{array}{l}2015 \\
2020 \\
2025 \\
2050\end{array}$ \\
\hline
\end{tabular}

一経済企画庁経済審議会「2010年の技術的予測」(1992年 7 月)上り拔粋一 


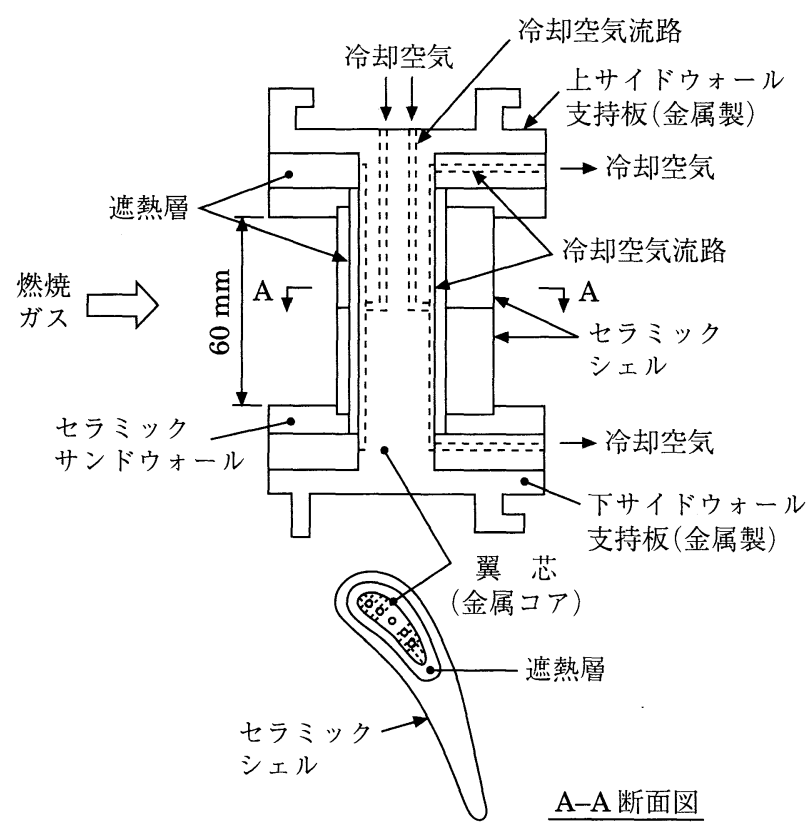

図 6 セラミック静翼の構造 ${ }^{(12)}$.

\section{4. おわりに}

地球環境問題に適切に対処するとともに, 電力の安定供給 を将来にわたり確保していくには，火力発電の高効率化が不 可欠である. それとともに，こここでは触れなかったが，環 境負荷の小さい原子力発電も主要な役割を果たす必要があ る.そのため，実績を積み重水てきた軽水炉発電の長期利用 とともに，エネルギーセキュリティの面からも準国産エネル ギーとして位置づけられる高速増殖炉の実用化など，より一
層安全で経済性の高い原子力発電技術の確立が求められてい る. いずれにしても，このような火力・原子力発電技術を支 えるベースとして，これから先も材料技術の進歩に期待する ところが大きいといえる。

最後に, 火力発電技術分野のエネルギー開発に括ける今後 の材料ニーズをまとめた表 2(14)を引用させていただき，本 稿の締めくくりとしたい.

\section{文献}

(1) 電力中央研究所 : 電中研レビュー, No. 29(1992).

（2）伊東正道, 河村祐士, 桑原和矢, 宮崎松生, 福井 寛, 竹田 頼正, 羽田壽夫, 石本礼二, 田村広治 : 火力原子力発電, 37 (1986), 727.

（3）齋藤哲朗, 狩野公男：日本ガスタービン学会誌，18(1990), 30.

（4）和食 靖：日本機械学会シンポジウム「動力・エネルギー技 術の最前線」Part II 講演論文集, No. 890-60(1989), 79.

（5）久保田道雄：火力原子力発電，42(1991), 228.

(6) D. W. Petrasek, D. L. McDanels, L. J. Westfall and J. R. Stephens: Metal Progress, 130(1986), 27.

( 7 ) M. F. Ashby: Phil. Trans. R. Soc. London, No. A322(1987), 393.

（8）経済企画庁経済審議会 : 2010年の技術的予測(1992).

（9）古谷春日, 肥爪彰夫, 藤川卓爾, 横田 宏, 国分孝友, 竹田 頼正：日本機械学会論文集 (B 編)，56(1990), 3889.

（10）塩入淳平 : 日本ガスタービン学会誌，19(1991), 4.

(11) EPRI : Report Ap-4475(1986).

（12）久松 暢, 阿部俊夫, 三巻利夫, 宮田 寛, 町田隆志, 大島 亮一郎：日本機械学会論文集 $(\mathrm{B}$ 編 $), \mathbf{5 7}(1991), 819$.

（13）土屋利明：日本ガスタービン学会誌, 18(1990), 6 .

（14）通商産業省基礎産業局新素材対策室監修：1993新素材便覧, (1993), 664 .

表 2 エネルギー開発に括ける材料ニーズ(14).

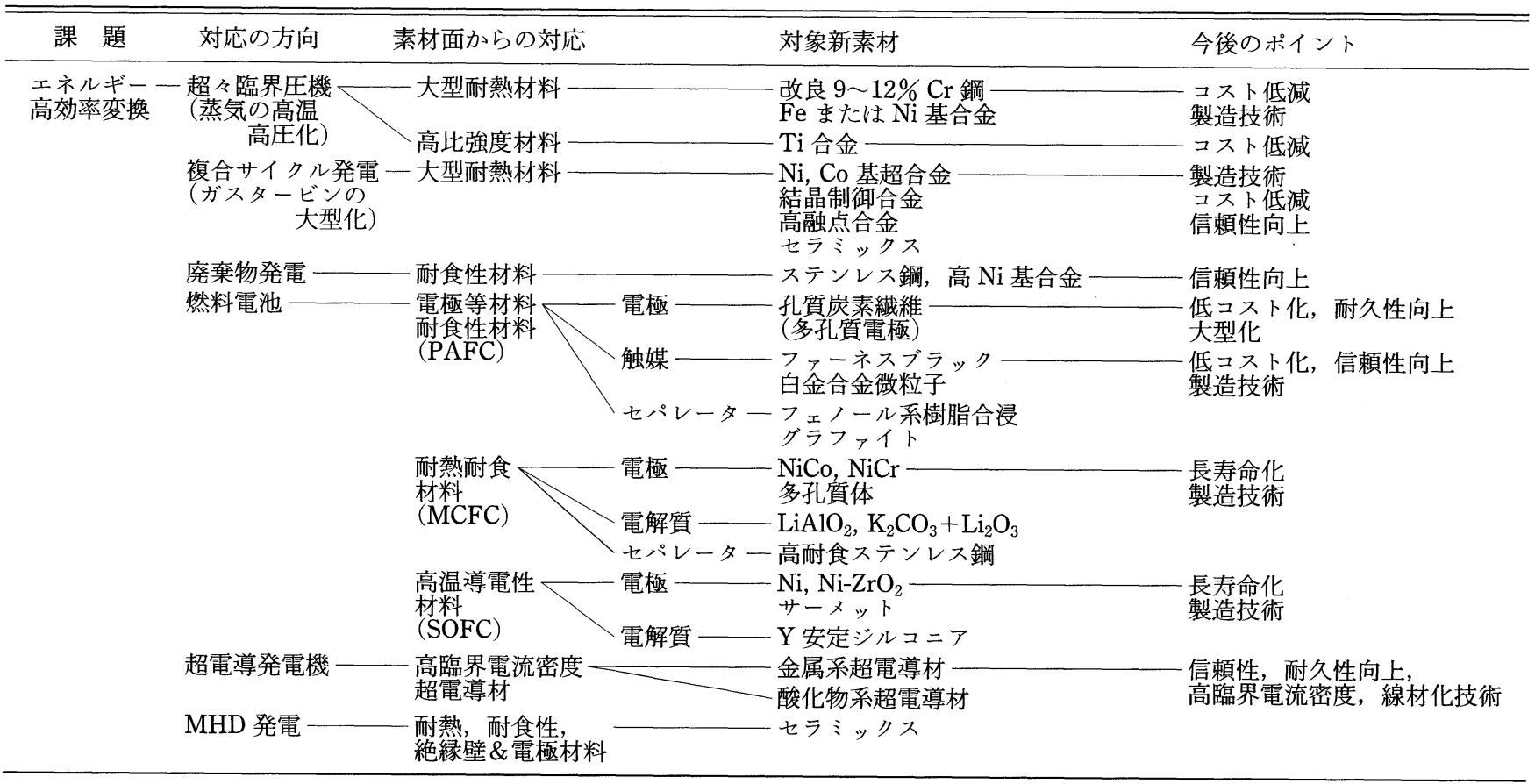

